\section{参考 文 献}

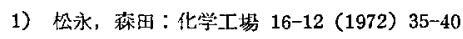

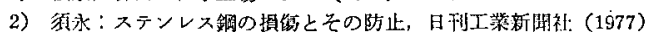

3) 珷川，三不，石丸：化学工学 44-3 (1980) 128-135

4) K. J. Irvine et a1. : J. I. S. I., 207 (1969), 1017

5) ASTM A412-1975

6) W.O. Binder, H. R. Spendelow : Trans Am. Soc. Met. 43 (1951), 759 777
7) R.A. Lula : Toughness of Ferritic Stainless Steels (1980), ASTM-STP No. 706

8) R.F. Steigerwald et al. : Corrosion 33-8 (1977), 279-295

9)跲木：鉄之銓 46-4 (1960) 498, 46-5（1960）578

10）中村：鉄と鋼 63-5 (1977) 872-882

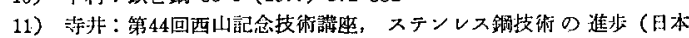
剑銅協会, 1977) 220-265

12) A.L. Shaeffler : Metal Prog. 56 (1949), 680

13) W.T. Delong et al. : Welding J. 35-11 (1956), 521-528

\title{
3. ニ相ステンレス鋼の溶接*
}

\author{
福井 \\ $太^{* *}$
}

Weldability of Duplux Stainless Steel*

by Futoshi Fukui**

\section{1 緒}

言

二相ステンレス鋼（以下二相鋼と呼ぶ）はオーステナ イト相とフェライト相の両相からなるステンレス鋼で主 として耐孔食性, 酎応力腐食割れ性を目的に開発され

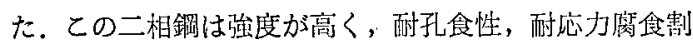
れ性，耐スキマ隼食性が従来のオーステナイト鋼やフェ ライト鋼にくらべすぐれているので化学プラント機器, 船舶用熱交に実用され好結果を得ている，又そのすぐれ た柎食性から他の分野でも注目されている鋼種である。

本報文では二相鋼の溶接に関運する諸現象について熱 的挙動, 溶接部の特性を中心に記述した。

\section{2 二相鋼の種類亡特徽}

二相鋼の一般的な組緎はフェラ.イト地にオーステナイ 卜相が分散しているもので固溶化熱処理状態ではその比 率はほ清1：1亿近い。

よく知られている市販鋼の種類と化学成分を表 3,1 K 示す.ほとんどのものが耐孔食鋼，耐応力腐食割れ鋼之 して開発されたが中には耐応力度食割れに㻎点をおいて 開発された NTK C-1, SANDVIK 3RE60 などがある.

AISI329 は昔からよく知られていたがわが国では1972 年に SUS329J1 として JIS 鋼種に規格化された。市肘 の各鋼種には Mo, N, Si, Cu, W などが目的に応じて

\footnotetext{
*原槁受的 昭和55年12月26日

**证具 日本金属不業(株) Meniber, Nippon Metal Industry Co. , Ltd.
}

添加されそれぞれ特徵をあたせている。

二相鋼の物理的機械约性犋は一般にオーステナイト紊 とフェライト系の中閶的な性質をむっているが二相銚特 有の性質むある。二相鋼の特徽を要約すると尚,

1) オーステナイト系にくらべて熱膨脹係数が小さ く, 热伝導度が大きい.

2）常温付近での強度，特に耐力が高いが, 高温強度 はオーステナイト系にくらべ小さい。

3）鞂性，延性はオーステナイト系よりも低い。

4）熱処理汒よる組織変化が大きく，耐食性をはじめ とする諸性質に影響を与える。

5）粒界腐食，応力腐食割れに対する抵抗性がある。 特に低灾力レベルでの抵挄性が大きく，高応力レベルで はオーステナイト系と同様割れやすい。

6）溶接時の高温割れ感受性は小さく溶接性は良い が，熱間冷閔加工性はオーステナイト系より劣る。

7）高 $\mathrm{Cr}$ 系で $\mathrm{Mo}, \mathrm{N}$ を含むるのは酎孔食性が大で ある。

\section{3 二相鋼の熱処理亡特性変化}

二相鋼は各種の熱処理によって組織変化を起とし，て れにとあなって酎食性や機械的性筫が变化する。主な変 化を要約すると，

\subsection{1 組織変化}

二相鋼を高温に加熱するとフェライト量が増加し結晶 粒の粗大化が生ずる．また各相中の組成す変化する。し 
福井：3. 二相ステンレス鎝の溶接

表 3.1 市販二相鋁の穗類と化学成分

\begin{tabular}{|c|c|c|c|c|c|c|c|c|c|}
\hline \multirow{2}{*}{\multicolumn{2}{|c|}{ 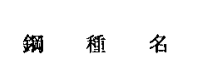 }} & \multicolumn{7}{|c|}{ (\%) } & \multirow{2}{*}{ 的i } \\
\hline & & c & $\mathrm{Si}_{\mathrm{i}}$ & $\mathrm{Mn}$ & $\mathrm{Cr}$ & $\mathrm{Ni}$ & Mo & その他 & \\
\hline \multicolumn{2}{|c|}{ NAS $45 \mathrm{M}$} & $\leq 0.03$ & $\leq 1.00$ & $\leq 1.50$ & $22.50 \sim 25.50$ & $4.00 \sim 6.00$ & $1.00 \sim 2.00$ & $\mathrm{Cu} 0.50 \sim 1.50$ & \multirow{2}{*}{ 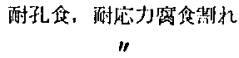 } \\
\hline \multicolumn{2}{|c|}{ NAR F } & $\leq 0.10$ & $\leq 1.00$ & $\leq 2.00$ & $24.0 \sim 26.0$ & $5.00 \sim 8.00$ & $1.50 \sim 2.50$ & N $0.10 \sim 0.15$ & \\
\hline \multicolumn{2}{|c|}{ NSS329M1 } & 0.025 & 0.39 & 0.57 & 25.82 & 4.96 & 1.50 & & \\
\hline \multicolumn{2}{|c|}{ DP3 } & $\leq 0.03$ & $\leq 0.75$ & $\leq 1.00$ & $24.0 \sim 26.0$ & $5.50 \sim 7.50$ & $2.50 \sim 3.50$ & $\mathrm{Cu}, \mathrm{w}$ & \multirow{2}{*}{ 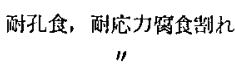 } \\
\hline \multicolumn{2}{|c|}{ NTKR-4 } & $\leq 0.03$ & $\leq 1.00$ & $\leq 1.00$ & $23.00 \sim 26.00$ & $4.00 \sim 6.00$ & $1.00 \sim 2.50$ & $N$ & \\
\hline \multicolumn{2}{|c|}{ NTKC-1 } & $\leq 0.04$ & $\leq 1.00$ & $\leq 2.00$ & $21.00 \sim 23.00$ & $4.00 \sim 5.50$ & & & \multirow{2}{*}{ 耐応力留食制れ } \\
\hline \multicolumn{2}{|c|}{ SUS329J1 } & $\leq 0.08$ & $\leq 1.00$ & $\leq 1.00$ & $23.00 \sim 28.00$ & $3.00 \sim 6.00$ & $1.00 \sim 3.00$ & & \\
\hline \multicolumn{2}{|c|}{ SANDVIK 3RE60 } & $\leq 0.06$ & 1.7 & 1.5 & 18.5 & 4.7 & 2.7 & & \multirow[t]{2}{*}{ 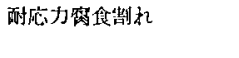 } \\
\hline \multirow{2}{*}{\multicolumn{2}{|c|}{ Uniloy 326}} & 0.04 & 0.40 & 0.50 & 26.0 & 6.5 & & $\mathrm{Ti} \quad 0.20$ & \\
\hline & is 50 & 0.03 & 0.5 & 0.5 & $20 \sim 30$ & $7 \sim 8$ & 2.5 & $\mathrm{Cu} \quad 1.5$ & 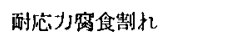 \\
\hline
\end{tabular}

たがって溶接入熱により熱影響部やボンド部の組織や組 成は母材部のそれらとはちがってくる，しかし固溶化熱 処理によって回復する現象が見られる。

\subsection{2 シグマ相の析出物およひ $475^{\circ} \mathrm{G}$ 脆化}

固溶化熱処理温度以下での加熱による組織変化として は主に700〜800て 付近でのシグマ相の析出およびこれよ りやや低温にノーズのある炭化物の析出である1. しか しオーステナイト相の存在のためフェライト単相の鋼に くらべて脆化の程度は少ない，また $475^{\circ} \mathrm{C}$ 脆化もフェラ イト単相鋼より緩和され特に低 $\mathrm{Cr}$ 二相鋼では $475{ }^{\circ} \mathrm{C}$ 脆 化をおこしにくい2).

\subsection{3 耐食性}

高温加熱によるオーステナイト量の減少は二相鎙の附 応力腐食割れ抵抗性を減少させる. 因 3.1 は耐志力腐食 割れ鍴である $21 \mathrm{Cr}-5 \mathrm{Ni}$ 二相鋼についての試験結榡で加 熱温度の上早と共にフェライト量が增加し破断奏命が短 かくなっている3)。柎孔食性す高温加熱やシグマ相の析 出によって影響をうける. 表 3.21）に示したように10\% $\mathrm{FeCl}_{3}$ 溶液による浸漬試験では固溶化熱処理状態の腐食 減量が $1 \mathrm{~g} / \mathrm{m}^{2} \cdot \mathrm{hr}$ 以下であるのに刘し $1300^{\circ} \mathrm{C}$ で30分間加 熱すると減量は $30 \sim 40 \mathrm{~g} / \mathrm{m}^{2} \cdot \mathrm{hr}$ にも達する.乙の $1300^{\circ} \mathrm{C}$ で加熱した試料を $500 \mathrm{C} \sim 1000^{\circ} \mathrm{C}$ でそれぞれ 5 分再加熱 した場合の腐食減量を見ると $500^{\circ} \mathrm{C} \sim 900^{\circ} \mathrm{C}$ の再加熱の效 果は殆んよ゙見られないが1000Cの再加憼によりほぼ固溶 化熱㚭理状態の值まで回復している，乙れは組織，組成 の変化とも対応している.

二相鋼の耐食性に対する熱処理の影響は応力腐食割れ および孔食に対して顕著にあらわれ，料界腐食や全面腐 食に対する影響は少ない。

\section{4 二相鉵の溶接と溶接部の特性}

\subsection{1 溶接施工}

二相鋼の溶接はオーステナイト鋼亡略同条件で行なう ことが出来る。通常 TIG 又は被覆ア、ク溶接法が適用

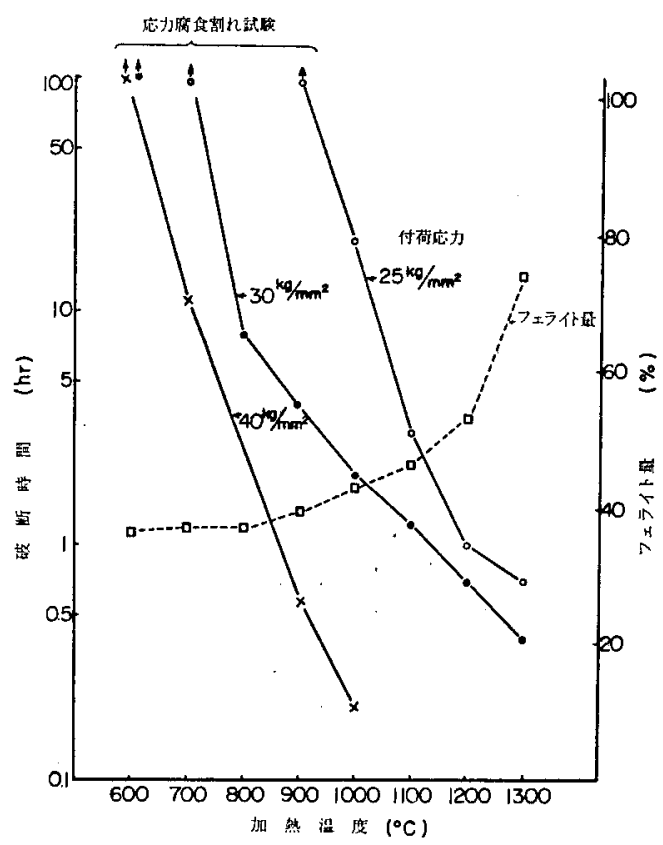

图 $3.121 \mathrm{Cr}-5 \mathrm{Ni}$ 二相鋼の応力腐食割れに対する 扣熱温度の影響（沸騰42\% $\mathrm{MgCl}_{2}$ 溶液）

されている，予熱後然は必要としないが入熱はできる限 り少なくする承が望ましい，表 3.3 亿市眅されている溶 材の銘俪亡全溶着金属あるいはワイヤーの化学成尔を示 す. 表 3.4 には溶接施工条件例を示す.

\section{4 .2 溶接部の組織と組成}

SUS329J1 型二相鋼の溶接継手の顕微鏡写真を図 3.2 および図 3.3 に示す. 図 3.2 は TIG 溶接継手, 図 3.3 は被覆アーク溶接継手である，写真からあ見られる通り 萟影響部で結晶粒の粗大化とオーステナイトの減少が 起っている.

$21 \mathrm{Cr}-5 \mathrm{Ni}$ 型二相鋼を TIG 溶接（溶加棒 $310 \mathrm{~S}$ ) した

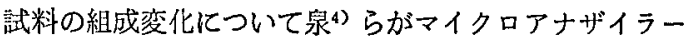
で测定した一例として次のように報告している。 
表 $3.2329 \mathrm{~J} 1$ 型二相鋼の耐食性に及ぼす高温加熱の影響

\begin{tabular}{|c|c|c|c|c|c|c|}
\hline \multirow[b]{2}{*}{ (A) } & \multirow{2}{*}{\multicolumn{2}{|c|}{$\frac{\text { 熱処理条件 }}{1050^{\circ} \mathrm{C}, \quad 10 \mathrm{~min}}$}} & \multicolumn{2}{|c|}{$\begin{array}{c}10 \% \mathrm{FeCl}_{3}+\mathrm{N} / 20 \mathrm{HCl} \\
30^{\circ} \mathrm{C}, 24 \mathrm{hr}\left(\mathrm{g} / \mathrm{m}^{2} \cdot \mathrm{hr}\right)\end{array}$} & \multicolumn{2}{|c|}{$\begin{array}{c}5 \% \mathrm{H}_{2} \mathrm{SO}_{4} \\
\text { Boil, } 6 \mathrm{hr}\left(\mathrm{g} / \mathrm{m}^{2} \cdot \mathrm{hr}\right)\end{array}$} \\
\hline & & & 0.10 & 0.23 & 2.3 & 1.5 \\
\hline (B) & (A) $+1300^{\circ} \mathrm{C}$, & $30 \mathrm{~min}$ & 31.7 & 39.1 & 3.2 & 4.5 \\
\hline (C) & (B) $+500^{\circ} \mathrm{C}$, & $5 \mathrm{~min}$ & 35.6 & 28.4 & 3.4 & 3.5 \\
\hline (D) & (B) $+600^{\circ} \mathrm{C}$, & $5 \mathrm{~min}$ & 26.1 & 28.1 & 8.1 & 9.1 \\
\hline (E) & (B) $+700^{\circ} \mathrm{C}$, & $5 \mathrm{~min}$ & 34.7 & 18.0 & 0.61 & 0.64 \\
\hline (F) & (B) $+800^{\circ} \mathrm{C}$, & $5 \mathrm{~min}$ & 26.5 & 24.9 & 0.29 & 0.36 \\
\hline (G) & (B) $+900^{\circ} \mathrm{C}$, & $5 \mathrm{~min}$ & 19.5 & 20.3 & 1.4 & 0.7 \\
\hline (H) & (B) $+1000^{\circ} \mathrm{C}$, & $5 \mathrm{~min}$ & 0.29 & 0.34 & 1.5 & 1.1 \\
\hline
\end{tabular}

表 3.3 二相鋼用の溶材と化学成分

\begin{tabular}{|c|c|c|c|c|c|c|c|c|}
\hline \multirow{2}{*}{ 銘唡 } & \multicolumn{7}{|c|}{ 成＼cjkstart分（溶着金属又はワイヤー）\% } & \multirow{2}{*}{ 䱜用銅 種 } \\
\hline & $\mathrm{C}$ & $\mathrm{Si}$ & $\mathrm{Mn}$ & $\mathrm{Cr}$ & $\mathrm{Ni}$ & Mo & その他 & \\
\hline WEL25-5 & 0.038 & 0.48 & 1.58 & 25.28 & 7.98 & 1.87 & & SUS329J1 \\
\hline WEL $25-5 \mathrm{Cu}$ & 0.022 & 0.62 & 0.45 & 24.33 & 8.24 & 1.91 & $\mathrm{Cu} 1.30$ & SUS329J1 Modify \\
\hline RNY R-4 & 0.028 & 0.26 & 0.74 & 24.29 & 7.11 & 1.96 & & SUS329J1 \\
\hline NAS $45 \mathrm{M}$ & 0.04 & 0.4 & 0.3 & 25.0 & 6.5 & 2.2 & $\mathrm{Cu}$ & $"$ \\
\hline NAR-F & $\leq 0.03$ & $\leq 1.50$ & $\leq 2.00$ & $24.0 \sim 26.0$ & $7.5 \sim 8.5$ & $1.50 \sim 2.50$ & & $"$ \\
\hline DP3 & 0.02 & 0.49 & 0.84 & 27.6 & 7.85 & 2.7 & $\begin{array}{l}\text { W } \\
\mathrm{Cu}\end{array}$ & $"$ \\
\hline
\end{tabular}

表 3.4 二相鋼の溶接施工例

\begin{tabular}{|c|c|c|c|c|c|c|c|c|}
\hline 形 & 状 & 厚 $(\mathrm{mm})$ さ & 先 & 溶接方法 & $\begin{array}{c}\text { 棒 䇮 } \\
(\mathrm{mm})\end{array}$ & シールドガス & 電 $(\mathbf{A})^{\text {流 }}$ & $\begin{array}{l}\text { 溶接速度 } \\
(\mathrm{cm} / \mathrm{min})\end{array}$ \\
\hline & & 10 & $\mathrm{~V}$ & 被澓ァーク & 4.0 & - & $120-160$ & $15 \sim 20$ \\
\hline & & 6 & $\mathrm{~V}$ & " & 3.2 & - & $100-120$ & 25 \\
\hline & & 6 & V & " & 3.2 & - & $150-170$ & 30 \\
\hline & & 3 & $\mathrm{v}$ & TIG & 2.6 & Ar & $90-120$ & $10 \sim 12$ \\
\hline & & $1.2 \sim 2.0$ & I & TIG & - & Ar & $110-150$ & $60 \sim 120$ \\
\hline
\end{tabular}

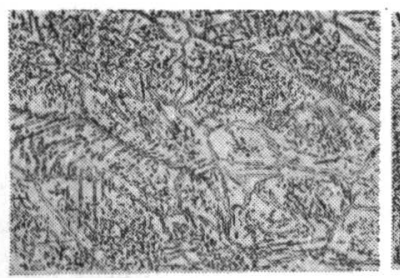

溶接金属部

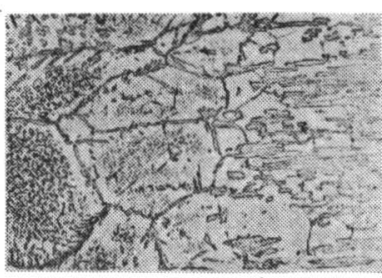

図 3.2 SUS 329J 1 型鋼の TIG 溶接継手の顕微鏡組織 $(\times 100)$

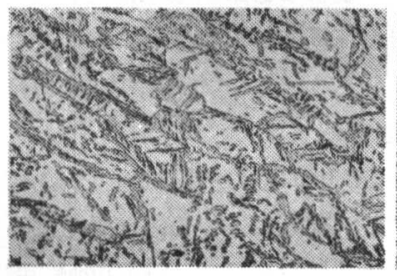

溶接金属部

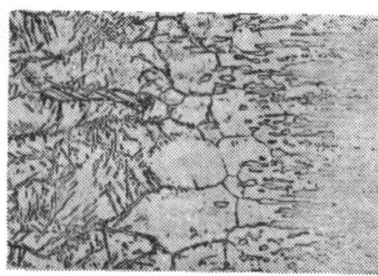
* HAZ * 母材部

図 3.3 SUS $329 \mathrm{~J} 1$ 型鋼の被覆アーク溶接継手の顕微 鏡組織

$(\times 100)$
1) 素材部 $\mathrm{Cr}: 21 \%, \mathrm{Ni}: 5 \%$ に対し $\mathrm{HAZ}$ は $\mathrm{Cr}: 20.5 \%, \mathrm{Ni}: 5.3 \%$.

2）組成の変動は素材部より $\mathrm{HAZ}$ の方が小 さい.

3) HAZ では素材部よりフェライト相で $\mathrm{Cr}$ が少なく，オーステナイト相では $\mathrm{Cr}$ が多くなっ ている.

\subsection{3 溶接部の機械的性質}

溶接金属の機械的性質の測定例を表 3.5 に示 す. TIG 溶接および被覆アーク溶接との間に大 きな差はないが, シャルピー衝撃值は TIG 溶接 の方が若干良好である. 溶接継手の機械的性質 試験例を表 $3.6^{5)}$, 表 3.76) に示す. 表 3.6 には SUS329J1 型二相鋼についてパス間温度の影響を 試験した結果を示した。ビード部のシャルピー衝 揧值は TIG 溶接が被覆アーク溶接にくらべ良好 であるがパス間温度の影響は殆んど認められな い. また母材にくらべ引張強さ, 衝撃値とも大幅 な低下は見られない. 図 3.45) に溶接部の硬さ分 
表 3.5 SUS329J 1 型二相鉡の溶着金属の機械的性質 (R.T)

\begin{tabular}{|c|c|c|c|c|c|c|c|c|}
\hline 溶接方法 & 染 伅 理 & 溶加诨 & 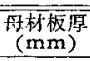 & 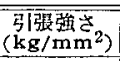 & $\begin{array}{c}\text { 耐 } \\
\left(\mathrm{kg} / \mathrm{mm}^{2}\right)\end{array}$ & $(\%)^{\text {U゙ }}$ & $\begin{array}{l}\text { 曲 } \\
(\mathrm{R}-\mathrm{t})\end{array}$ & (Hv) \\
\hline TIG & As welded & 共金 & - & 50 & (1) or & 25 & O. K & 281 \\
\hline 被彯ナーク & $"$ & $"$ & 12 & 80 & 67 & 24 & $\mathrm{O} \cdot \mathrm{K}$ & 267 \\
\hline$"$ & $"$ & $"$ & 19 & 80 & 69 & 24 & - & - \\
\hline$"$ & $"$ & $"$ & 10 & 82 & 64 & 27 & - & - \\
\hline
\end{tabular}

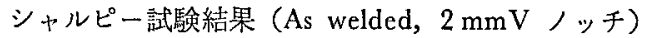

\begin{tabular}{|c|c|c|c|c|}
\hline \multirow{2}{*}{ 溶接方法 } & \multirow{2}{*}{ 溶 加桂 } & \multicolumn{3}{|c|}{ シャルピー衝娐値 $\left(\mathrm{kg} \cdot \mathrm{m} / \mathrm{cm}^{2}\right)$} \\
\hline & & $-20^{\circ} \mathrm{C}$ & $0^{\circ} \mathrm{C}$ & K. T \\
\hline TIG & 共金 $(3.2 \phi)$ & 6.1 & 8.7 & 10.8 \\
\hline 被覆ナーク & $"$ & 4.5 & 4.9 & 6.2 \\
\hline
\end{tabular}

表 3.6 329J 1 型二相鋼の溶接継手の機械的性質 $(\mathrm{R} . \mathrm{T})$

\begin{tabular}{|c|c|c|c|c|c|}
\hline \multirow{2}{*}{ 溶接方法 } & \multirow{2}{*}{\multicolumn{2}{|c|}{ バス間冾却* }} & \multirow{2}{*}{$\begin{array}{c}\text { 引張強さ } \\
\left(\mathrm{kg} / \mathrm{mm}^{2}\right)\end{array}$} & \multicolumn{2}{|c|}{ 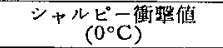 } \\
\hline & & & & ビード部 & ボンド部 \\
\hline \multirow{3}{*}{ TIG } & 水 & 命 & 79 & 12.1 & 10.7 \\
\hline & 쪼 & 冷 & 79 & 12.8 & 10.5 \\
\hline & 事 & 縨 & 78 & 10.2 & 10.4 \\
\hline \multirow{3}{*}{ 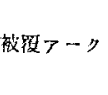 } & 水 & 冾 & 80 & 7.5 & 10.8 \\
\hline & 然 & 冷 & 81 & 7.4 & 10.8 \\
\hline & 䞞 & 続 & 78 & 7.3 & 10.6 \\
\hline \multicolumn{3}{|c|}{ 柆 材 $(15 \mathrm{~mm}$ 㙞) } & 80 & $\begin{array}{c}\text { 压延直员 } \\
10.3\end{array}$ & $\begin{array}{c}\text { 压延平行 } \\
14.9\end{array}$ \\
\hline
\end{tabular}

*水深 $<50^{\circ} \mathrm{C}$, 空冷 $<100^{\circ} \mathrm{C}$, 速繶 $100 \sim 250^{\circ} \mathrm{C}$.

表 $3.721 \mathrm{Cr}-5 \mathrm{Ni}$ 二㥵鍮 の突合甘溶接部の引張強 さ及び曲げ角度

\begin{tabular}{|c|c|c|c|}
\hline 溶 加 楱 & $\begin{array}{c}\text { 引張強さ } \\
\left(\mathrm{kggf} / \mathrm{mm}^{2}\right)\end{array}$ & 破断位罢 & $\begin{array}{l}\text { 曲战角度 } \\
(\mathrm{R}=2 \mathrm{t})\end{array}$ \\
\hline 共金 & 67.2 & 溶接金属部 & $180^{\circ}$ 以上 \\
\hline Y 308 & 67.6 & " & " \\
\hline Y 309 & 68.4 & $"$ & $"$ \\
\hline Y 310 & 65.8 & $"$ & $"$ \\
\hline （母 材） & (67.8) & & \\
\hline
\end{tabular}

板厚 $6 \mathrm{~mm}$ TIG

布を示す．表 3.7 から見られるように $21 \mathrm{Cr}-5 \mathrm{Ni}$ 系の溶 接継手の強度は溶接棒の種類によって特に大きな差はな いが，D310 の場合はやや強度が低くなっている。

\subsection{4 溶接部の耐食性}

二相堸の母材の耐食性はかなりすぐれているが溶接部 は溶接入熱の影響をうり前述のように組織変化を生ず る.すなわち熱影響部ではフェライト相が多くなりオー ステナイト相が少なくなるため酎食性が劣化しやすい. しかし溶接入䓡を極力小さくすると共に冷却速度を速く する等施工上の配虑で少化を最小限们抑えられる、材料 面からは成分元素の配合を考虑し，例えば N の添加や Mo 含有量を高めるてとで耐食性の改善を図っている6). 各種の溶接方法を用いて耐食性への影響を. X2 CrNiMo

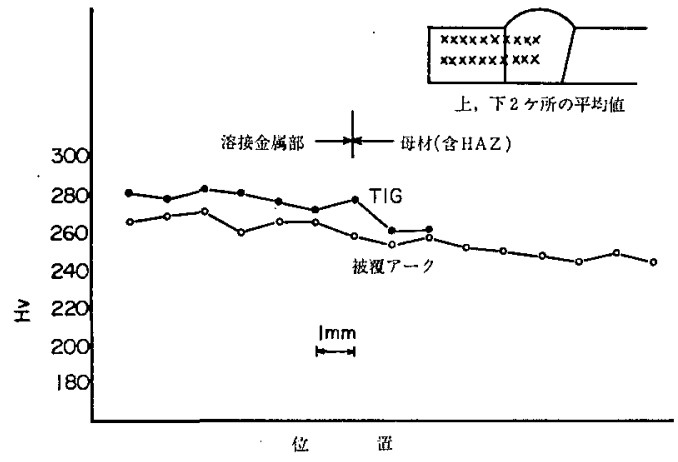

図 $3.4329 \mathrm{~J} 1$ 型二相鍶の溶接継手の硬さ分布

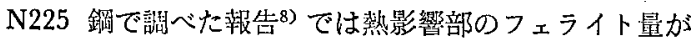
60\%を超えることがなく，したがって熱影響部の耐食性 は大きく劣化することはないといわれている，耐応力腐 食割れ鋼である $21 \mathrm{Cr}-5 \mathrm{Ni}$ (NTK C-1) の溶接試料につ いての応力腐食割れ試験と65\%硝酸試験結果の一例を表 3. $8^{77}$ に示す.リング状に肉盛溶接した試料の $42 \% \mathrm{MgCl}_{2}$ 溶液中での応力腐食割れ試験結果である. SUS304 に比 較して初期割れ発生時間屯かなり長くなっており耐応力 属食割れ鋼としてその特徵がうかがえる. 表 3.91$)$ には SUS329J1 型二相銅の65\%硝酸試験結果を母材之溶接継 手について示した，溶接のままです耐硝酸性は劣化して いない，なお溶接部の耐食性に関しては小若 ${ }^{6) ら の く わ ~}$ しい報告がある。

\subsection{5 溶接部の疲れ強さ}

Cr 21.7\%, Ni 5.25\%, C $0.02 \%$ の溶接武料（溶加棒 Y310S TIG溶接)について試験した鼠》)らの結果では, 片振引張瘦れ武験の疲れ限度は母材で $38.4 \mathrm{~kg} / \mathrm{mm}^{2}$, 溶 接材で 32〜33 kg/mm² と余り大きな低下は見られない. また溶接電流の高い試料（余盛仵 $37^{\circ}$ ）の方が低い試料 (余盛角 $18^{\circ}$ ) よりやや疲れ限度が高くなっている，329 
表 3.8 $21 \mathrm{Cr}-5 \mathrm{Ni}$ 二相銅の溶接試料腐食試験結果

\begin{tabular}{|c|c|c|c|}
\hline \multirow[b]{2}{*}{ 器加棒 } & \multicolumn{2}{|c|}{ 応力窝食割れ陚験* } & \multirow{2}{*}{$\begin{array}{c}65 \% \text { 硝酸試駿** } \\
\left(\mathrm{g} / \mathrm{m}^{2} \cdot \mathrm{hr}\right)\end{array}$} \\
\hline & 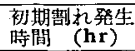 & 㲅机発生位睓 & \\
\hline D 347 & $1 \sim 2$ & 塂 界 部 & - \\
\hline D 309 & $11 \sim 27$ & $"$ & 0.21 \\
\hline D 310 & $26 \sim 50$ & $" \prime$ & 0.18 \\
\hline $\begin{array}{l}\text { Fy-15 SUS304 } \\
\text { D } 308\end{array}$ & $2 \sim 4$ & 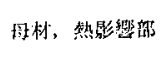 & - \\
\hline
\end{tabular}

*リング肉盛竗精 $42 \% \mathrm{MgCl}_{2}$ 溶液

** $65 \% \mathrm{HNO}_{3}$ 泓婘 $48 \mathrm{hr} 3$ period 平均

表 3.9 SUS329J 1 型二相鋼の65\%硝酸試験絬柴

\begin{tabular}{|c|c|c|c|}
\hline 試 & 料 & 熱処理 & $\begin{array}{l}\text { 蜜食減量 } \\
\left(\mathrm{g} / \mathrm{m}^{2} \cdot \mathrm{hr}\right)\end{array}$ \\
\hline \multirow{2}{*}{$\begin{array}{l}\text { SUS } 329 \mathrm{~J} 1 \text { 型 } \\
(25 \mathrm{Cr}-5 \mathrm{Ni}- \\
2 \mathrm{Mo}-\mathrm{N})\end{array}$} & $2 \mathrm{~mm}$ 朕 & $\begin{array}{l}\text { 囷滵化熱处理 } \\
475^{\circ} \mathrm{C} \times 4 \mathrm{hr} \\
650^{\circ} \mathrm{C} \times 2 \mathrm{hr} \\
1300^{\circ} \mathrm{C} \times 5 \mathrm{~min}\end{array}$ & $\begin{array}{l}0.12 \\
0.13 \\
0.30 \\
0.59\end{array}$ \\
\hline & 溶接継手 & 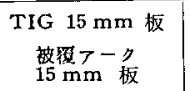 & $\begin{array}{l}0.15 \\
0.14\end{array}$ \\
\hline
\end{tabular}

J1 型二相销间の回枟曲げ波れ試験では母材の疫れ限度 43 $\mathrm{kg} / \mathrm{mm}^{2}$, 洪金溶接材 $36 \mathrm{~kg} / \mathrm{mm}^{2}$ という試騟結果もあ る.

\subsection{6 溶接部の時効特性}

$\mathrm{Cr}: 17.84 \%, \mathrm{Ni}: 4.87 \%, \mathrm{Mo}: 2.48 \%, \mathrm{C}: 0.041 \%$

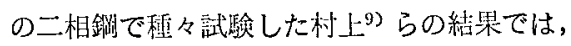

(1) 二相鋼の時効処理による敬性低下にはシグマ相脆 化が関与している。

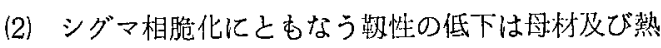
影響部で同栐な挙動を示す．乙れはシグマ相がオーステ ナイト相の析出を伴って变態することに関係している。

(3) $475^{\circ} \mathrm{C}$ 脆化比よる靱性の低下は母材及び就影響部 で珙なっている．とれはフェライト相の粒径に依存して いるものと若えられる。

(4) $800 〜 900^{\circ} \mathrm{C}$ の最高到達温度の奘サイクルを与える と $475^{\circ} \mathrm{C}$ 脆化は抑制される。

\subsection{7 溶接施工上の注意事項}

二相鋼の溶接に際し一般的な施工基準はオーステナイ 卜糸と同様である。特に留意すべき点としては，入熱量 を少なくすること，アークストライクを母材部で行わな いとと，開先面を清浄にするとと等であるう．との他二 相鋼は水素脆化によってビード部が制れるととがあるの でシールドガスに $\mathrm{H}_{2}$ ガスを混合するととはさけたすが よい. 純 Ar ガスの使用が望ましい.

\section{5 溶接後の熱処理}

溶接部の組織变化にともなう耐食性や機械的性質の劣 化估熱処理によって回復する。二相鋼の烧なまし熱処理
表 3.10 SUS329J 1 型二相銅の応力腐食割れに対す る応力除去熱処理の效果

\begin{tabular}{|c|c|c|}
\hline $\begin{array}{c}\text { 熱処理賈度 } \\
\left({ }^{\circ} \mathrm{C}\right)\end{array}$ & $\begin{array}{c}\text { 加蠜時 } \\
\text { (hr) }\end{array}$ & $\begin{array}{c}\text { 例れ発生時間 } \\
(\mathrm{hr})\end{array}$ \\
\hline 溶接のまま & - & 1 \\
\hline 500 & $\begin{array}{l}1 \\
2 \\
3\end{array}$ & $\begin{array}{c}3 \\
8 \\
>1.000\end{array}$ \\
\hline 600 & $\begin{array}{c}5 \mathrm{~min} \\
30 \mathrm{~min} \\
1 \\
2\end{array}$ & $\begin{array}{l}>1.000 \\
>1.000 \\
>1.000 \\
>1.000\end{array}$ \\
\hline
\end{tabular}

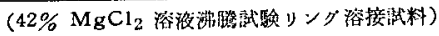

は1000 1100 ${ }^{\circ}$ 亿加熱後急冷する. 冷却速度は速いほど 靶性，预食性共に良好となる。尚 $21 \mathrm{Cr}-5 \mathrm{Ni}$ 鍓（NTK

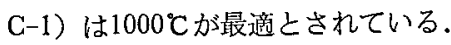

650〜850 Cでの加熱はシグマ相の析出によって鞄性， 耐食性に影響をおよぼす。したがって応力除去熱処理は 一般には推奖できないが必要とされる場合は 900 C 以上 に加熱して空冷するか， $600^{\circ} \mathrm{C}$ 前後の比較的低温で処理 するととが望ましい，応力腐食制れの防止には $600^{\circ} \mathrm{C}$ 前 後の短時間加等でかなりの效果があり，粒界腐食の心配 あない. SUS329J1 型二相銓の応力腐食制れに対する応 力除法热処理の刘果を試験した結果の一例を表3.10に示 す5).

\section{6 実用例}

二相鋼の笑用例としては応力隭食割れ及び孔食に対す る抵抗性を利用したものが多いが高強度をあわせるって いるので遙心分離機や高压ポンプ部品に使用されてい る.

淡水環境では工業用水，河川水，地下水など淡水を冷 却水上する熱交換器に使用され好結果を得ている。実用 例の塩菜イオン濃度及びプロセス僛の温度は最高 1150 ppm, $180^{\circ} \mathrm{C}$ よっている”.

海水熱交の伝熱管として銅合金管に代り，1960年頃よ り実用化されており使用開始当初の事故を除けばほぼ满 足できる結果を得ている．主として化学工業用として使 用された海水熱交の使用結果を解析した水野9)の報告で は,

（1）熱交の事故は熱点腐食による局部的腐食生成物の 発生, 成長, 固着により誘発されたスキマ鹰食によるす のである。

（2）したがって熱点腐食を生じさせ好対策として生物 発生をなくすとと，海水中浮遊物の流入を防ぐてと， 冷却海水の流速を速設計值として $1.5 \mathrm{~m} / \mathrm{sec}$ 以上にす る. 
（3）熱交使用領域としては熱交の型式にもよるが，王 力 $\mathrm{P}\left(\mathrm{kg} / \mathrm{cm}^{2}\right) \times$ 温度 $\mathrm{t}\left({ }^{\circ} \mathrm{C}\right)$ K関し

(i) コンデンサー： $\mathrm{P} \times \mathrm{t}$ を略60以下にする

(ii) クーラー $: \mathrm{P} \times \mathrm{t}$ を咯100以下にする の結果が得られている.

この他塩化物，リン酸環境などであ熱交の伝染管とし ての使用実績屯多い。

\section{7 む ひ}

二相鋼のすぐれた耐食性や強度などの特徵を十分に生 かすためには，溶接部をいかに劣化させないかにかかっ ている. 本鋼種は熱影響に対して敏感であるので溶接施 工に当っては材料の特性を十分理解し適切な溶接条件で 行なう必要がある，材料面からの改良之共に奏用データ の積重ね浪よる利用技術の開発が望まれる。

\section{参 考 文 献}

1）㸟田：耐食二相ステンレ大龢，防食技街，26（1977）721-730

2) SANDVIK 补瓷料

3) M. Watanabe, T. Suzuki, G. Shinoda: Microanalysis of a two-phase Stainless Steel. Proceedings of the 6 th International Conference on X-ray optics and microanalysis (1972), 713-717

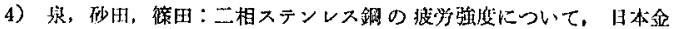
政学会辞，35 (1971) 324-330

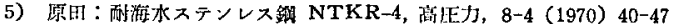

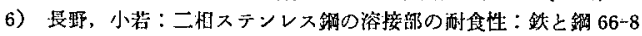
(1980) $1150-1159$

7）鈴木：オーステナイトーフェライト二相ステンレス端の鲆究，学 位䯍女

8) W. Wessling, H. E. Bock : Properties and applications of recentry developed Feגrite/Austenite Steel Containing $0.02 \% \mathrm{C}, 22 \% \mathrm{Cr}, 3 \% \mathrm{Mo}$ and $0.12 \% \mathrm{~N}$ in Comparison with Mo-alloyed Austenite steels, Stainless Steel a Global Forum 77, paper 16 (1977)

9）村上，池内，酮，河原：フェライト一オーステナイト系二相ス テンレス鋼溶接部门特奻特性，本蒜 49-3 (1980) 213-219

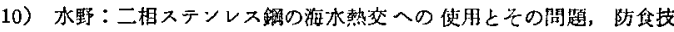
術, 27 (1978) 291-300

\section{4. 高シリコンステンレス鋼の溶接*}

画

䦓

勤**

Welding of the High Si Stainless Steels*

by Tutomu Nishima

\section{4. 高シリコンステンレス鋼の溶接}

\section{1 高シリコンステンレス鋼の特性}

オーステナイトステンレス鎆で耐食耐㷫用として， あっとあ広く使用されている鋼程は SUS304 であり,一 般化学工業用の耐食用として広く沉用されている銅種は SUS316 である。また耐熱鐵としては SUH310，SUS $310 \mathrm{~S}$ が沉用されている。乙れら沉用銅に対して高シリ コンステンレス鋼は当初耐応力厤食割れ（SCC）䤱とし て開発され，その後耐酸化性および高温高濃度の硝酸に 対する優れた耐食性等で，乙れらの用途位刘する，いわ ば尃用鍋種として発達して来た。

以下に該鎝種の特性についてのへ，次章で溶接上の問 題点について述へるととにする.

*原稿受付 昭和 56 年 1 月 6 日

**日本治金工業(秼) Nippon Yakin Kogyo Co., Itd

\subsection{1 化学組成之機械的性質}

表 4.1 亿該鋼種の化学總成とメーカー各社の闾品名を 示す。まず耐食用では $18 \mathrm{Cr}-13 \mathrm{Ni}-4 \mathrm{Si}$ で代表される SUS XM 15J に包含されるあのが多く,メーカーによっ ては $\mathrm{Cu}$ 入りや P を規制したものむ散見される，SCR -2，3 は Si は低目であるが $\mathrm{Ni} ， \mathrm{Cr}$ が高目になってい る.

耐熱用としての一つK SUS302B があり，各社とあ 302B の記号を使用している。すう一つに SUS XM 15J に包含されるものがある，また NTK309B は SUH309 に Si を高くしたあのである。

常温機械的性質の規格值は，SUS304，316 と同一レ心゙ ルであり耐力 $21 \mathrm{~kg} / \mathrm{mm}^{2}$, 引張り強さ $53 \mathrm{~kg} / \mathrm{mm}^{2}$ 以上 である．また，図 4.1 亿高温短時間引張り試験の一例を 示し, ASME code Sect VIII Div 2 亿規定されている TYPE316 の 耐力保証值を併記したが，乙れを十分に上 